\title{
MANAJEMEN KONFLIK DALAM GEREJA MULA-MULA: TAFSIR KISAH PARA RASUL 2:41-47
}

\author{
Frans Paillin Rumbi \\ Sekolah Tinggi Agama Kristen Negeri Toraja \\ Jl. Poros Makale-Mengkendek, Km.11.5, Kampus STAKN Toraja, \\ Kec. Mengendek, Kab. Tana Toraja, Propinsi Sulawesi Selatan \\ Email: fransrumbi24@gmail.com
}

\begin{abstract}
Frans Paillin Rumbi, Conflict Management in The Early Church: Interpretation of the Acts 2:41-47. The main question put forward in this study is that in the early church there was no conflict? On that basis, the writer tries to find answers by using library research methods with the reader response interpretation approach. The result seems to be that the congregation was originally formed in the midst of conflict. Furthermore, in the early days they were confronted with internal and external conflicts. Internal conflicts include inner conflicts related to their waiting for the Kingdom of God and inner conflicts of individualistic and materialistic. The choice between prioritizing one's own welfare or having to share with others. To overcome the various conflicts that arise, they try to process it by first consistently building alliances on the basis of the work of the Holy Spirit. Furthermore, they developed a lifestyle based on the spirit of repentance and desire to renew the way of life, practicing the teachings of the Lord Jesus and the Apostles by promoting solidarity with others and controlling individualistic and materialist attitudes, building intensive communication in order to create mutual understanding and mutual understanding.
\end{abstract}

Keywords: Management, Conflict, Community, Solidarity, Communication

\begin{abstract}
Abstrak: Frans Paillin Rumbi, Manajemen Konflik Dalam Gereja Mula-mula: Tafsir Kisah Para Rasul 2:41-47. Pertanyaan utama yang diajukan dalam penelitian ini adalah benarkah dalam jemaat mula-mula tidak ada konflik? Atas dasar itu, maka penulis mencoba mencari jawab dengan mengunakan metode penelitian pustaka dengan pendekatan tafsir reader response. Hasilnya tampak bahwa jemaat mula-mula terbentuk di tengah-tengah konflik. Selanjutnya pada masa-masa awal mereka telah diperhadapkan dengan konflik baik internal maupun ekstenal. Konflik internal antara lain berupa konflik batin berkaitan penantian mereka atas Kerajaan Allah serta konflik batin berupa individualistis dan materialistik. Pilihan antara mementingkan kesejahteraan sendiri atau harus berbagi dengan orang lain. Untuk mengatasi berbagai konflik yang muncul, mereka berusaha mengolahnya dengan pertama-tama konsisten membangun persekutuan di atas landasan karya Roh Kudus. Selanjutnya mereka mengembangkan pola hidup yang dilandasi semangat pertobatan dan keinginan memperbaharui cara hidup, mempraktekkan pengajaran Tuhan Yesus dan para Rasul dengan mengedepankan solidaritas kepada sesama serta mengendalikan sikap individualitik dan materialis, membangun komunikasi yang intensif agar tercipta kesehatian atau saling pengertian satu sama lain.
\end{abstract}

Kata Kunci: Manajemen, Konflik, Komunitas, Solidaritas, Komunikasi

\section{PENDAHULUAN}

Konflik hampir tak terelakkan dari kehidupan bermasyarakat. Umumnya konflik dipicu oleh perbedaan pemahaman dan kepentingan, di mana salah satu bahkan semua pihak yang bertikai berusaha memaksakan kehendaknya untuk diikuti oleh pihak lain. Mieu (2014, pp. 100-101) mengelompokkan jenis-jenis konflik menjadi enam bagian. 1) Konflik laten yakni konflik tersembunyi yang sewaktu-waktu dapat meledak; 2) Konflik terbuka yakni konflik yang mencuat kepermukaan yang mewujud melalui permusuhan dari pihak-pihak yang bertikai; 3) Konflik langsung terjadi apabila individu atau kelompok-kelompok saling menghalangi, saling berjuang demi mencapai tujuan tertentu; 4) Konflik tidak langsung, di mana antar individu dan kelompok tidak saling berhadapan tetapi saling menghalangi untuk mencapai tujuan masing-masing; 5) Konflik tanpa 
kekerasan, biasanya berupa konflik gagasan, nilai dan norma serta tidak terjadi kekerasan fisik; 6) Konflik kekerasan, yang menggunakan tindak kekerasan untuk menghancurkan lawan. Pengelompokan tersebut memperlihatkan bahwa dua atau lebih jenis konflik sering terkait satu dengan yang lain. Dilihat dari segi motifnya nampak bahwa konflik terjadi karena perbedaan pandangan sehingga memicu munculnya unsur kompetisi atau persaingan untuk meyakinkan kelompok lain maupun menaklukannya. Apabila konflik tidak diatur atau selesaikan dengan baik, maka aspek negatif yang akan berkembang, sebaliknya pengelolaan yang baik, membuat konflik memberi sumbangsih terhadap kemajuan peradaban. Dengan kata lain konflik dapat memicu persatuan internal maupun eksternal pada individu maupun kelompok-kelompok yang bertikai.

Seperti dalam kehidupan bermasyarakat, gereja acapkali berhadapan dengan konflik. Baik yang dipicu ketidakpuasan sesama anggota jemaat (internal) maupun pengaruh dari luar (eksternal). Beberapa faktor internal antara lain manajemen gerejawi, keuangan, program kerja maupun kebijakan lainnya. Faktor eksternal seperti dinamika sosial ekonomi, politik, ideologi, budaya dan agama masyarakat. Ada juga konflik yang sengaja diciptakan oleh oknum tertentu dalam jemaat setempat untuk mewujudkan kepentingan-kepentingannya.

Faktanya konflik yang tidak ditangani secara tepat dan berlangsung dalam jangka waktu lama akan memengaruhi kesatuan jemaat, bahkan membuat masalah menjadi lebih kompleks. Konflik di GKJST dapat menjadi contoh. Pada mulanya terjadi konflik pribadi tetapi berkembang menjadi konflik yang luas dan melibatkan jemaat (Sarioa, 2014, pp. 54-60). Resolusi konflik yang tepat dapat merangsang pertumbuhan jemaat.

Untuk mencegah dan mengatasi konflik, jemaat perlu ditata sedemikian rupa melalui manajemen konflik. Menurut Rusdiana manajemen konflik adalah usaha mengarahkan pihak-pihak tertentu - individu yang bersangkutan, individu dengan individu, individu dengan kelompok dan kelompok de- ngan kelompok - menciptakan perdamaian dan kesatuan. Manajemen konflik merupakan usaha yang integral mulai dari pencegahan sampai dengan penanganan masalah (Rusdiana, 2015, p.170). Dapat dikatakan, manajeman konflik lebih pada unsur penataan untuk mencegah konflik. Manajemen konflik dibutuhkan untuk menghindari dampak yang lebih luas serta perselisihan dalam jangka waktu lama. Manajemen konflik dibutuhkan untuk membentuk relasi yang lebih baik. Entah mengusahakan situasi yang mirip di masa lampau sebelum terjadi konflik, ataupun menuju ketahapan yang lebih maju di mana mereka tampil dengan gaya dan pola hidup yang baru, sebuah bentuk perdamaian yang baru.

Manajemen konflik dibutuhkan sebagai langkah pencegahan terjadinya konflik, tetapi jika sudah terjadi konflik, maka manajemen konflik lebih mengarah pada resolusi konflik. Model tersebut dapat dijumpai pada gereja mula-mula khususnya dalam Kisah Para Rasul 2:41-47. Gereja seringkali memberitakan kehidupan jemaat mula-mula sebagai pola ideal berjemaat karena komunitas tersebut dipandang "adem-ayem" (tenang-damai). Pandangan tersebut nampak dalam penelitian Sutoyo (2004, p.2) yang menjelaskan bahwa gereja mula-mula mengalami pertumbuhan karena setia dan taat belajar firman Tuhan. Nainggolan (2018, p.92) menggambarkan ketekunan dan semangat membangun persekutuan membuat gereja mengalami pertumbuhan. Untuk memperkaya pemahaman tersebut, maka penulis menggunakan sudut pandang berbeda. Penulis justru mencurigai agenda tertentu dari Lukas kepada jemaat yang menjadi tujuan penulisan kitab. Secara sosiologis, ketika ketekunan dan persekutuan tibatiba ditekankan, mengindikasikan di dalam kehidupan jemaat sedang terjadi ketegangan atau konflik.

Istilah persekutuan berasal dari bahasa Latin communion artinya komunal atau persekutuan yang akrab, perjamuan kudus (Napel, 2005, p. 81). Persekutuan yang benar-benar menunjukkan kesatuan akan tercapai apabila semua anggota komunitas mampu mengembangkan semangat kekeluargaan serta rasa saling menghargai satu dengan yang lain. 
Akan tetapi benarkah dalam jemaat mula-mula tidak ada konflik? Untuk menjawab pertanyaan tersebut, penelitian ini berusaha menelusuri konteks hidup jemaat mula-mula supaya dapat tampil secara utuh dinamika kehidupan berjemaat. Jika terjadi konflik, maka ingin diperlihatkan model resolusi konflik. Tetapi jika tidak ada, maka ingin diperlihatkan model penataan dan pencegahan konflik. Dengan kedua praduga itulah, penulis ingin memperlihatkan cara mereka mengolah manajemen konflik.

\section{METODE}

Penelitian ini menggunakan metode penelitian pustaka yang menekankan pendekatan reader response atau tanggapan pembaca (Singgih, 2009, p. xiii). Singgih (2016, pp. 51-55) menjelaskan bahwa model ini memberi ruang kepada pembaca untuk memahami teks dengan mengajukan model hermeneutik kecurigaan atau kritik ideologi, tetapi tetap berangkat dari pola dasar penafsiran yakni pembacaan naskah asli dari teks Alkitab (Ibrani dan Yunani). Pada model penafsiran reader response informasi data serta penyajiannya ditentukan oleh interaksi antara pembaca dengan teks yang dikaji, atau sebaliknya teks dengan pembaca. Penafsirlah yang mencoba mengungkap makna-makna baru dari teks melalui dialog mendengarkan pengalaman si pembaca. Penjelasan Prior (2010, pp.7-8) mengungkapkan cara kerja analisis data pendekatan ini. Untuk menemukan makna teks, pembaca perlu berkomitmen dan mendedikasikan hidupnya. Pada posisi ini teks dan pembaca saling berhadap-hadapan, tetapi bukan sebagai lawan melainkan saling mendengarkan. Tujuannya untuk mendapatkan sumber kebijaksanaan atau pemahaman yang baru.

Berdasarkan uraian tersebut, penulis berangkat dari prapaham bahwa jemaat mula-mula juga berhadapan dengan masalah (konflik) yang dapat mengarah pada perpecahan. Pandangan inilah yang coba penulis kaji untuk mendapatkan pemahaman mengenai situasi yang sesungguhnya terjadi dalam kehidupan jemaat.

\section{HASIL DAN PEMBAHASAN}

\section{Keadaan Jemaat Mula-Mula}

Jemaat mula-mula mewartakan Kerajaan Allah seperti yang diajarkan Yesus. Kerajaan Allah digambarkan sebagai kehidupan yang adil, damai dan sejahtera. Mereka mengedepankan hospitalitas dan solidaritas kepada yang menderita, yang tertindas, mengalami ketidakadilan serta diskriminasi. Gaya hidup tersebut menarik minat Lukas, sehingga ia membagikan kisah mereka kepada Teofilus maupun jemaat yang menjadi tujuan kitab Lukas dan Kisah Para Rasul. Kisah Lukas dan Kisah Para Rasul perlu diceritakan karena Mandaru (2007, p. 36) menegaskan, secara historis jemaat Lukas berhadapan dengan penindasan baik yang disebabkan oleh para penguasa Romawi maupun penguasa lokal. Harta milik mereka disita, mereka dikucilkan bahkan terancam hukuman mati. Berhadapan dengan kenyataan tersebut Lukas menyarankan dua hal bagi jemaat, yakni: Pertama, bagi mereka yang sedang dituntut pada persoalan melepaskan iman atau harta milik, maka disarankan untuk melepaskan harta milik. Kedua, mereka yang memiliki harta diharapkan bersikap dermawan dan menujukkan hospitalitas kepada mereka yang kehilangan harta milik demi mempertahankan imannya pada Kristus.

Mencermati tuntutan yang muncul, tampak bahwa jemaat mula-mula sedang mengalami konflik. Kalaupun dalam teks Kisah Para Rasul 2:41-47 tidak secara jelas digambarkan pertikaian dalam jemaat, tetapi dari dari penelusuran pada teks-teks yang lebih awal dan akhir, nampak bahwa mereka mengalami konflik laten. Menurut Rusdiana (2015, pp. 165-166) konflik laten yakni konflik yang belum muncul dipermukaan karena secara emosional masalah yang timbul masih bisa dikendalikan. Jemaat mula-mula tidak terpancing melakukan kekerasan, sekalipun mereka disindir oleh umat yang menganut yudaisme, pemuka agamanya serta tekanan sosial yang ditimbulkan oleh pemerintahan Romawi. Kemungkinan jemaat mampu meredam situasi tersebut sedikit banyak karena kesadaran bahwa mereka in- 
ferior dibanding komunitas yang besar. Mereka tidak memiliki kekuatan dan pengaruh yang cukup kuat dalam masyarakat.

Lukas menguraikan sejarah terbentuknya jemaat serta cara mereka memeraktekkan ideologi Kerajaan Allah melalui kepedulian satu dengan yang lain. Namun mereka tidak sedang memperjuangkan ideologi dan gaya hidup komunis, seperti yang seringkali dituduhkan banyak pihak (pembaca masa kini). Para sosialis justru terinspirasi dari gaya hidup mereka, yang meujud dalam gaya hidup komunis. Gaya hidup ini muncul sebagai kritikan atas modernitas yang cenderung individualis (Craig, 1943, p. 142). Komunisme menentang kepemilikan akumulasi modal pada individu. Pada masyarakat yang mengembangkan gaya demikian, seluruh alat-alat produksi harus dikuasi oleh negara untuk diolah dan dipergunakan untuk mengusahakan kesejahteraan rakyat. Sementara itu, Colpe (1993, p. 91) menolak kalau pola hidup jemaat mula-mula disebut komunis, egalitarian dan kolektivisme. Ia cenderung menyukai istilah consumer cooperative (Kis 5:4). Misalnya, Karl Marx seorang Yahudi beragama Kristen yang dididik dalam pendidikan liberal menilai bahwa model kepemilikan bersama atas sarana-sarana produksi akan menghancurkan alienasi di antara manusia (Campbell, 1994, p. 144). Ideologi yang diusung oleh komunisme adalah terciptanya sebuah masyarakat tanpa kelas. Dalam pola hidup demikian, ketiadaan struktur sosial dapat diganti dengan hukum yang mengatur kepemilikan dan masyarakat melaksanakan kontrol sosial secara bersama-sama. Marx percaya model tersebut dapat menekan konflik sosial. Pada masyarakat ini, produksi barang dilakukan untuk memenuhi kebutuhan, bukan untuk mencari keuntungan (Campbell, 1994, p. 155).

\section{Terbentuknya Jemaat Mula-mula}

Kisah dimulai dengan laporan penerimaan simpatisan ke dalam komunitas gerakan Yesus (ay. 41). Teks Alkitab berbahasa Yunani (GNT) menggunakan kata nen (men) artinya sungguh-sungguh. Kata men menjelaskan perkataan Petrus telah membuat pendengarnya bereaksi. Kelompok yang menerima perkataan Petrus memutuskan untuk memberi diri dibaptis. Alkitab Terjemahan Baru (TB) menggunakan kalimat "orang-orang yang menerima". Sebaliknya, kelompok yang menolak perkataan Petrus enggan memberi diri dibaptis. Perbedaan reaksi pendengar menuntun pada konteks perkataan (khotbah) Petrus untuk melihat ketegangan seperti apa yang terjadi diantara para murid dan orang-orang Yahudi.

Segera terlihat setelah peristiwa Pentakosta mendapat respons negatif dari sebagian orang, yakni mereka yang menyaksikan peristiwa menakjubkan dari orang-orang yang mengalami kepenuhan Roh Kudus. Inilah konflik pertama, yang memantik reaksi Petrus sehingga ia mengecam dan membela jemaat mula-mula dari sindirian orang-orang disekitarnya (Kis. 2:13, 14). Baptisan menjadi tanda inisiasi (penerimaan) kepada mereka yang bertobat (ay. 38) dan pertobatan terjadi karena pekerjaan Allah (ay. 33 menampilkan kesatuan Allah, Yesus dan Roh Kudus dalam karya). Banyak orang memberi diri untuk dibaptis sehingga jumlah anggota jemaat mencapai 3000 jiwa (ay. 41). Kehadiran Roh Kudus menandai transisi tugas pemberitaan Injil Kerajaan Allah dari Yesus kepada murid-murid. Roh Kudus memampukan Petrus (murid-murid) untuk meyakinkan pendengarnya agar menerima Injil Kerajaan Allah. Keyakinan Petrus bersama murid-murid lainnya tentang Yesus turut membentuk keyakinan para pendengar untuk menerima Yesus dan memberi diri untuk dibaptis. Dari segi pendengar, Roh Kudus diyakini mengerakkan para simpatisan untuk menyisihkan individualitas mereka dan mulai menjiwai hidup komunitas (Colpe, 1993, pp. 76, 83).

Selain aspek spiritualitas, kehadiran jemaat mula-mula sedikit-banyak dipengaruhi kekecewaan atas penyalahgunaan kekuasan dari pemerintah Romawi dan petinggi Yudaisme. Jemaat-jemaat hidup dalam intimidasi maupun persekusi (Sanderan, 2015, p. 104). Kedua penguasa bertanggungjawab terhadap peristiwa penyaliban Yesus. Mereka menolak perubahan dan pengharapan yang dibawa Yesus bagi masyarakat pada zamannya (ay. 22, 23). 
Jemaat mula-mula menampilkan perjuangan yang lebih elegan. Berbeda dengan golongan asketis dan gerakan revolusioner yang cenderung ekstrim menuntut perubahan. Jemaat mula-mula tampil dengan gerakan non kekerasan. Mereka pun tidak mengasingkan diri dari masyarakat seperti komunitas esseni. Bagi murid-murid, menafikan hak kepemilikan dan kekuasaan yang menindas merupakan "semangat baru" yang dipercaya dapat membawa perubahan.

Para rasul menyadari ada tantangan yang menyertai terbentuknya jemaat mula-mula yakni keragaman budaya anggota jemaat. Melalui peristiwa pentakosta diperoleh keterangan bahwa mereka berasal dari enam belas daerah. Meskipun teks tidak secara langsung mengungkapkan masalah yang ditimbulkan oleh perbedaan budaya, tetapi tidak dapat menafikan bahwa semangat primordial sering kali menyebabkan konflik. Bahkan di bagian lain kitab Kisah Para Rasul dijelaskan mengenai perselisihan antara orang Yahudi berbahasa Yunani dengan orang Ibrani (Kis. 6:1). Bartlett (2007, p. 166) mencurigai telah terjadi proses penyaduran peristiwa konflik oleh Lukas. Di mana Lukas dengan segaja mengolah kisah yang menonjolkan aspek keharmonisan. Tampaknya Lukas berusaha mengatasi perselisihan dan mempertahankan kesatuan dalam jemaat.

Para rasul menggunakan pendekatan tradisi untuk menumbuhkan kebersamaan pada jemaat. Hal tersebut terlihat melalui kebiasaan berkumpul dan makan bersama. Jemaat menggunakan kesempatan berkumpul untuk membicarakan beberapa persoalan serta memanfaatkan kesempatan tersebut membicarakan berbagai hal yang dapat menimbulkan konflik, maupun mencegahnya. Kegiatan makan bersama berasal dari tradisi bangsa Yahudi dan sekitarnya, seperti diungkapkan lewat tulisan-tulisan Perjanjian Lama (mis: perjanjian Yakub dan Laban di Kejadian 31:46) dalam kitab Lukas pun Yesus meneruskan tradisi tersebut, salah satunya melalui peristiwa makan bersama dengan 5000 orang (Luk 9:10-17). Lebih konkrit lagi, jamuan makan terakhir yang Yesus lakukan bersama para murid (Kis 1:4) merupakan penguatan atas selesainya konflik iman dan ke- takutan yang baru saja dialami umat atas peristiwa kematian Yesus. Guthrie (2012, p. 60) menekankan bahwa ibadat dan kebiasaan makan bersama yang sering dilakukan oleh jemaat mula-mula menjadi sarana untuk mempererat persekutuan. Melalui kebiasaan tersebut, jemaat berusaha mewujudkan kesatuan dalam Yesus Kristus.

Dalam Kisah Para Rasul 2:43 terjemahan GNT menggunakankata de (de) yang artinya "tetapi" atau "dan". Berbeda dengan Alkitab berbahasa Indonesia TB yang menggunakan kata "maka". Kata "maka" menunjukkan sebab akibat dan tidak berkesinambungan dengan kalimat pada ayat 43. Tidak mungkin peristiwa makan bersama menyebabkan mereka yang hadir merasa ketakutan. Lagi pula tidak ada keterangan tentang kekacauan pada peristiwa makan bersama. Oleh karena itu, penulis mengusulkan kata de diterjemahkan dengan "dan" yang merupakan kata hubung. Kata "dan" bisa digunakan untuk menyatakan hubungan yang setara, hal lain dari tema yang sama ataupun keadaan lain. Dalam teks kata de atau "dan" dapat digunakan untuk menjembatani peralihan waktu dari ayat 42 dan ayat-ayat selanjutnya.

Kata "dan" menjadi petunjuk untuk mencari tahu penyebab jemaat merasa ketakutan. Dalam terjemahan GNT kata ketakutan disebut phobos (ay.43). Kata ini merupakan kata benda yang menerangkan sesuatu yang tunggal yang menyebabkan ketakutan atau pun teror. Kata "ketakutan" nampaknya menerangkan suasana lain yang dialami di luar acara makan bersama. Berkaitan dengan perasaan jemaat ketika melihat mujizat dan tanda yang dilakukan oleh para rasul. Ketakutan yang dimaksud nampaknya bernada positif, diawali ketakutan atas sesuatu yang belum pernah dilihat tetapi memuncak pada takjub atau kekaguman. Umumnya pada komunitas atau organisasi yang baru terbentuk, hal-hal yang luar biasa serta tidak mampu dilakukan oleh komunitas lain, dikelola untuk menguatkan kelompok serta menjadi alasan berbangga. Dengan demikian mujizat dan tanda dalam konteks teks tidak menyebabkan ketakutan melainkan sukacita. 
Ketakutan dapat menandakan adanya konflik batin dari individu jemaat. Tidak tertutup kemungkinan kata "ketakutan" mewakili keadaan yang sesungguhnya. Ketakutan muncul ketika seseorang merasa terancam atas kesalahannya. Juga terjadi karena orang lain merasa tersaingi sehingga berniat jahat kepada dirinya. Berdasarkan prinsip itu, maka ketakutan dalam teks erat kaitannya dengan kehadiran komunitas. Ketakutan dapat muncul dan dipengaruhi oleh faktor luar komunitas. Kehadiran jemaat mula-mula dipandang sebagai ancaman oleh komunitas lain. Tampaknya yang paling merasa terancam yakni penganut agama Yahudi mengingat komunitas jemaat mula-mula dipandang sebagai kemunculan sekte lain dari agama Yahudi (Kis. 24:5).

Jika dikaitkan dengan peristiwa Yesus, ketakutan pun dialami oleh orang-orang Yahudi setelah mendengar kisah kebangkitan Yesus. Sebuah perenungan terhadap kecaman Petrus atas kekejaman yang dilakukan orang Yahudi terhadap Yesus (2:23b). Dari segi keanggotaan, peningkatan pesat anggota jemaat sejak peristiwa kebangkitan Yesus menimbulkan iri hati dan kekuatiran dari kalangan pemuka agama Yahudi (Kis. 5:17). Para penganut dan atau pimpinan agama Yahudi merasa kuatir kehilangan pengaruh dalam masyarakat akibat pertambahan anggota jemaat Kristen secara signifikan. Selain itu, kekuatiran atas munculnya aksi tak terduga seperti mobilisasi massa yang akan menuntut balas atas peristiwa Yesus. Telah menggerakkan mereka melaksanakan usaha represif kepada jemaat seperti yang disaksikan dalam gerakan Saulus (Kis. 8:3). Jadi hendak ditegaskan bahwa ketakutan tidak hanya mengarah pada perasaan takjub jemaat, ketakutan atas ancaman yang dapat muncul dari luar, serta ketakutan dari orang-orang Yahudi atas aksi balasan yang dapat muncul dari komunitas jemaat yang semakin besar. Itulah salah satu konflik yang terjadi dalam jemaat mula-mula dan orang Yahudi.

\section{Solidaritas Jemat Mula-mula}

Solidaritas diimani sebagai hasil pekerjaan Roh Kudus. Namun sekali lagi, harus memberi tem- pat pada keterlibatan manusia dalam menumbuh kembangkan solidaritas. Hal yang dimaksud yakni peranan rasul-rasul dalam membentuk solidaritas jemaat dengan meneruskan manajemen penatalayanan Yesus.

Awalnya para rasul mengembangkan solidaritas hanya untuk kalangan sendiri. Mereka tidak membentuk struktur kepemimpinan layaknya organisasi kemasyarakatan dan keagamaan. Sepertinya mereka menyadari bahwa struktur dapat menimbulkan perpecahan. Struktur kepemimpinan berpotensi menciptakan dominasi pihak yang berkuasa.

Pada komunitas tanpa struktur sosial atau struktur kepemimpinan, yang diandalkan adalah komitmen bersama dari para anggota untuk bersamasama mewujudkan kebersamaan. Terkait dengan kehidupan jemaat mula-mula, mereka dituntut memberitakan Injil secara bersama-sama. Dengan cara itu juga, mereka mampu menyisihkan faktor individualistis, serentak dengan itu mereka dapat saling menghargai, menerima satu dengan yang lain.

Para rasul mengajarkan tentang nilai-nilai solidaritas. Di antaranya mengatasi sikap materialistik sebab diyakini dapat menyebabkan penderitaan dan perpecahan dalam jemaat. Materialistik merupakan sikap hidup yang berorientasi pengumpulan dan penguasaan harta sebanyak-banyaknya, yang mana seseorang lebih mementingkan diri sendiri dan kurang peduli kepada sesama yang membutuhkan bantuan. Pada ayat 44 dikatakan "segala kepunyaan mereka adalah kepunyaan bersama." Teks ingin menunjukkan bahwa jemaat yang baru mengembangkan sebuah solidaritas. Bersamaan dengan itu, mereka berusaha mengatasi sikap materialistik dan keserakahan.

\section{Hidup Tanpa Hak Milik}

Theissen (2005, pp. 19-28) mencatat ciri gerakan Yesus yakni meninggalkan rumah, keluarga, harta milik dan perlindungan. Pola meninggalkan keluarga dan harta milik paling jelas terjadi dalam jemaat mula-mula. Konsekuensi dari intensitas pertemuan adalah berkurangnya waktu berkumpul dengan anggota keluarga tetapi menguatkan solidaritas 
dikalangan anggota komunitas. Menurut Theissen (2005, p. 23), gerakan Yesus yang mewajibkan setiap orang membenci keluarganya telah menimbulkan pertentangan antara pengikut Yesus dengan keluarganya.

Kebiasaan menjual harta milik dan membagi hasil jualan berhasil menghindarkan mereka dari sikap materialistik (ay 45). Namun tidak menjamin bahwa jemaat memahami model tersebut dengan baik, apalagi para rasul tidak terang-terangan mengajarkan cara hidup menjemaat. Ini terbukti pada kasus Ananias dan Safira (Kis. 5:1-11). Kisah tersebut meninggalkan pesan bahwa individu jemaat mengalami konflik batin ketika harus membagi hasil jualannya, sehingga mereka harus menyembunyikan hasil penjualan hartanya dengan diam-diam dan melaporkan kepada para rasul tidak sesuai dengan kenyataan. Sepertinya mereka mengalami dilema, enggan berbagi mencirikan sikap yang tidak solider sebaliknya konsekuensi berbagi yakni hanya sedikit hasil penjualan yang dapat dinikmati. Tidak tertutup kemungkinan semua hasil penjualan diserahkan dan dibagi kepada anggota komunitas. Konflik yang dialami lumrah dari sisi manusia. Berdasarkan hasil penelitian Sihombing (2015, p.174) tampak bahwa jemaat tidak memahami bahwa personal right tetap dihargai. Di mana hak kepemilikan seseorang tetap mendapat tempat.

Penting dipertanyakan, apa yang membuat jemaat mula-mula memiliki solidaritas yang sangat kuat? Apakah karena pengaruh dari khotbah Petrus yang "menakutkan"? Situasi tertekan yang dialami bersama (penderitaan) nampaknya menjadi faktor utama yang memperkuat solidaritas jemaat mulamula. Usaha mengubah penderitaan menuntut semua pihak berjuang demi kebebasan. Mereka yakin salah satu usaha yang dapat ditempuh untuk memupuk persatuan adalah kerelaaan saling menolong dan berbagi. Dengan tindakan tersebut, seseorang akan merasa bahwa ia diperhatikan oleh orang lain. Perasaan itu memotivasinya untuk solider kepada sesama yang lain, yang juga membutuhkan pertolongan.

Faktor lain yakni jemaat mula-mula berorientasi pada masa penantian kedatangan Yesus yang tidak lama lagi. Untuk memastikan mereka tetap berada dalam kelompok yang diselamatkan, maka perlu meningkatkan kebaikan kepada sesama. Liem Khim Yang (2007, p. 147) mengambarkan bahwa persekutuan jemaat mula-mula menghindari pembedaan asal-usul keturunan, status atau kedudukan sosial, lalu kemudian mewujudkan persekutuan hidup sebagai manusia baru. Pendapat berbeda dikemukakan oleh Colpe (1993, p. 83), menurutnya jemaat yang baru tidak lagi berorientasi pada kedatangan Yesus dalam waktu dekat, melainkan melanjutkan kehadiran di waktu yang tak terhitung.

\section{Perjamuan Makan}

Bagian kedua dari kebiasaan makan bersama jemaat mula-mula (ayat 46) memperlihatkan bahwa sejak terbentuknya jemaat, mereka menganggap perlu memasukkan peringatan perjamuan malam terakhir sebelum Yesus disalibkan, ke dalam liturgi gereja. Jemaat merayakannya dengan gembira dan tulus hati. Suasana yang menyenangkan dengan sendirinya meneduhkan suasana hati. Pada akhirnya mereka mampu meninggalkan konflik batin. Demikian juga membuka ruang untuk terbuka dan menerima musuh menjadi teman. Kegembiraan merupakan salah satu ciri dari pekerjaan Roh Kudus dan menunjukkan keyakinan jemaat tentang kehadiran Tuhan Yesus di antara mereka (Marshall, 2007, p. 85).

Perayaan dengan gembira dimaksudkan supaya jemaat mampu menghayati makna saling menerima, saling mengakui, saling memaafkan dan bersedia membangun kehidupan bersama dalam Kristus. Melalui peristiwa makan bersama, maka penyedia dan penerima bergembira bersama. Serentak dengan itu, mereka mengabaikan aturan-aturan meja makan yang lebih ketat seperti dalam adat istiadat bangsa Yahudi, yang mana sistem ketahiran amat ditekankan. Sebagaimana diketahui, masyarakat Yahudi memberlakukan aturan ketat terhadap jenis makanan yang dapat dikonsumsi, cara menyediakannya bahkan dengan siapa mereka dapat makan.

Dalam jemaat mula-mula tindakan menolak makan bersama merupakan bentuk protes sosial 
tetapi sekaligus sebagai cara mengasingkan diri dari komunitas. Sedangkan orang Farisi (dan lainnya) menolak makan bersama dengan orang-orang yang dianggap najis. Bagi mereka orang najis sejajar dengan sampah masyarakat. Makan bersama merupakan sebuah mikrokosmos sistem sosial, duduk makan semeja dengan orang lain adalah sebuah penjelmaan wawasan sosial (Borg, 2000, p. 66).

\section{Konflik Lain Yang Menyertai Terbentuknya Jemaat}

Beberapa bagian konflik sudah tampil pada pembahasan keadaan jemaat mula-mula. Konflikkonflik itu menyangkut relasi antara jemaat dengan orang-orang Yahudi, maupun konflik batin yang dialami oleh individu sekitar keputusan mereka beriman kepada Kristus. Tetapi masih ada konflik lain yang terungkap dalam ayat-ayat yang mendahului dan sesudah pembacaan teks Kisah Para Rasul 2:4147. Konflik-konflik tersebut turut digumuli oleh jemaat, antara lain: Pertama, Pertanyaan para murid tentang restorasi "Tuhan, maukah Engkau pada masa ini memulihkan kerajaan bagi Israel" (Kis 1:6). Teks tidak hanya menampilkan masalah iman, tetapi juga mengungkapkan harapan para murid-murid tentang keadaan baik, yang jauh dari ketimpangan sosial dan terjaminnya keamanan. Mereka berharap terjadi pembaruan dalam tatanan pemerintahan maupun keagamaan. Dari ketidakadilan menjadi keadilan, memulihkan hak-hak kemanusiaan dan sebagainya. Kedua, Konflik iman nampak dalam seruan Petrus tentang pertobatan (Kis 2:38). Pertama-tama seruan ditujukan kepada mereka yang sedang mendengar pidato tersebut yakni orang Yahudi kemudian semua penduduk Yerusalem. Pertobatan menandakan adanya konflik atau ketegangan dalam relasi manusia dengan Tuhan, terjadi penyimpangan terhadap kehendak Tuhan. Pertobatan merupakan bentuk perdamai-an dengan Tuhan, yang memungkinkan relasi denganNya kembali menjadi baik. Ketiga, Setelah kenaikan Yesus, jemaat cenderung mengadakan pertemuan secara tertutup atau sembunyi-sembunyi (Luk. 24:33).
Itu dilakukan untuk menghindari ancaman dari pemuka agama Yahudi dan para pemilik kekuasaan.

\section{Cara Mencegah Konflik}

Jemaat mula-mula sangat peka terhadap konflik atau masalah yang timbul. Sebab itu, setiap pertemuan dimanfaatkan untuk mencegah serta mencari solusi atas konflik muncul dalam jemaat. Berikut cara mencegah dan mengatasi konflik pada jemaat mula-mula:

\section{Pertobatan dan Pembaruan (Ay. 41)}

Inisiasi baptisan merupakan tanda seseorang menyatakan dan diakui sebagai bagian dari persekutuan umat Kristiani. Baptisan sebagaimana yang diungkapkan dalam teks merupakan tanda kesediaan memberi diri kepada Allah, sebagai bentuk kesadaran dan keinginan membaharui segala sesuatu. Baik berkenaan dengan pola pikir dan tindakan yang diklasifikasikan sebagai dosa sehingga yang bersangkutan dapat "hidup baru". Namun, penulis tidak bermaksud mengarahkan agar setiap anggota gereja yang berkonflik harus dibaptis kembali. Melainkan supaya mereka menjiwai semangat baptisan sebagai dasar mengupayakan perdamaian. Konflik dapat meluas jika pihak-pihak yang bertikai tidak menyadari dan mengingini perdamaian. Menyelesaikan konflik bukan sekedar mencari siapa yang benar dan siapa yang salah. Sebab pihak-pihak yang terlibat konflik cenderung mempertahankan kebenaran dalam perspektifnya masing-masing. Perdamaian dapat terjadi apabila pihak-pihak yang berkonflik (individu maupun kelompok) sadar dan berkomitmen untuk meredakan ketegangan serta mewujudkan perdamaian yang holistik. Melalui sikap seperti itu, terbuka jalan untuk saling menerima keberadaan dalam segala bentuk perbedaan identitas, kebudayaan dan karakter. Perdamaian juga harus dimulai dengan menurunkan egoisme pribadi maupun kelompok.

\section{Bertekun Dalam Pengajaran Rasul-rasul (Ay. 42)}

Konflik dapat teratasi apabila usaha perdamaian dilakukan menurut pengajaran rasul-rasul. 
Intinya menekankan sikap mengikut ajaran Yesus yakni membalas kejahatan dengan kebaikan, kekerasan dengan tanpa kekerasan. Selanjutnya ketika perdamaian sudah terwujud, perlu memupuk kasih kepada sesama manusia. Berkaca pada konflik-konflik yang terjadi di Indonesia, penyebab meningkatnya konflik adalah tidak adanya semangat perdamaian. Konflik justru diatasi dengan kekerasan, akibatnya muncul luka baru dari orang-orang yang merasa tersakiti. Dalam keadaan terpaksa sekalipun, kekerasan harus dihindari demi terciptanya perdamaian. Ketika kekerasan berhadapan dengan kekerasan yang terjadi justru memicu berbagai bentuk kekerasan lain.

Pihak-pihak yang berkonflik terkadang mengadakan agresi kepada pihak ketiga yang lemah, karena dianggap yang bersangkutan tidak berani mengadakan perlawanan. Kepadanya pelaku agresi merasa bebas melampiaskan emosi. Kehidupan rumah tangga menjadi contoh yang paling sederhana, anak seringkali menjadi sasaran dari konflik yang terjadi pada orangtuanya.

\section{Pertemuan Intensif dan Komunikasi (Ay. 42, 46b)}

Para rasul menyadari dengan semakin banyak pertemuan, maka semakin terbuka kesempatan untuk saling mengenal, menguatkan dan membangun ideologi bersama. Pertemuan menjadi kesempatan untuk mengkomunikasikan berbagai permasalahan yang timbul baik kesulitan maupun konflik dalam jemaat. Salah satu ciri religius dari jemaat mulamula yakni mereka berkumpul dalam Bait Allah tiap-tiap hari. Mereka percaya dengan ikut mengambil bagian pada persembahan korban bakaran yang dipimpin oleh para rasul, berdoa dan menerima berkat dari para rasul, mereka sedang membangun hubungan yang benar dengan Mesias (Marshall, 2007, p. 85). Adapun hal utama yang tidak dapat dilepaskan dari praktek komunikasi yakni makan bersama dan berdoa.

\section{Makan}

Dalam Alkitab, tradisi makan bersama dipelihara bahkan digunakan Yesus untuk membangun persekutuan dengan umat-Nya (perjamun kudus). Peristiwa tersebut dilanjutkan oleh para murid (jemaat mula-mula) untuk membina persekutuan di antara mereka. Cara ini pun dipandang sebagai bagian dari kesaksian iman (Tanhidy, 2014, pp. 126-127). Menarik memerhatikan kebiasaan itu karena konflik Yesus dengan gerakan Farisi salah satunya dipicu persoalan makan. Yesus tidak menggunakan adat istiadat Yahudi dengan ketat terkait dengan jamuan makan. Yesus makan bersama dengan siapa saja tanpa memedulikan konsep tahir dan najis, Yesus makan bersama dengan orang berdosa (den Hyer, 1997, p. 20-21).

Tradisi umat Yahudi zaman Perjanjian Lama memperlihatkan keluasan fungsi makan bersama. bukan hanya untuk merayakan kegembiraan tetapi juga ketika berhadapan dengan dukacita. Jadi dalam meja makan ada tangisan dan ada tawa (den Hyer, 1997, p. 23). Bangsa-bangsa lain menggunakan tradisi makan bersama sebagai kesempatan menyelesaikan konflik. Melalui makan bersama, pihak-pihak yang bertikai mengkomunikasikan kesalahpahaman, kecurigaan, kejengkelan dan berbagai perasaan tidak enak yang terjadi di antara mereka. Komunikasi biasanya melibatkan pihak ketiga sebagai mediator yang nantinya akan mengarahkan pembicaraan. Seorang mediator biasanya berasal dari kalangan orang yang memiliki integritas, dan kapabilitas dan dihormati oleh pihak bertikai yakni kepala suku, tua-tua adat maupun tokoh agama. Mediator harus netral, dihormati, memiliki kemampuan mendengar dan meneliti dengan cermat duduk perkara yang menyebabkan konflik. Maksudnya supaya mereka dapat mengarahkan pihak-pihak bertikai dalam menyelesaikan konflik. Akhirnya komunikasi ditutup dengan makan bersama sebagai tanda selesainya masalah dan tidak ada lagi perasaan dendam.

Suku-suku di Indonesia juga memiliki tradisi makan bersama, dengan kandungan makna yang cukup luas. Apabila dilakukan oleh dua orang atau kelompok yang awalnya berseteru tetapi kemudian berdamai, makan bersama merupakan tanda bahwa masalah telah selesai dan tidak ada lagi dendam 
yang tersimpan. Pada kesempatan lain, makan bersama sering dilakukan setiap kali mengadakan pengucapan syukur, sebagai tanda bahwa si pemilik acara ingin berbagi sukacita dari kerabat dengan teman yang hadir. Pada kebiasaan itu juga terkandung makna penerimaan dan penyelesaian konflik antara pengundang dan yang diundang.

\section{Doa}

Komunikasi kepada sesama tidak dapat berjalan dengan baik tanpa campur tangan dari Allah. Berangkat dari kesadaran itu, pihak-pihak yang berkonflik perlu mengkomunikasikan masalah dan upaya penyelesaiannya kepada Allah lewat doa. Doa diyakini sebagai jalan bagi umat untuk memperoleh pencerahan dari Allah, menjadi penuntun utama untuk memaafkan dan menerima lawan menjadi kawan.

\section{Menumbuhkan Kesehatian (ay 46a)}

Perdamaian hanya bersifat temporal jikalau kedua belah pihak tidak sehati dalam menjalani masa-masa perdamaian. Memaafkan (tanda perdamaian) memang mudah tetapi melupakan susah. Terbukti mudahnya pihak-pihak yang telah berdamai mengingkari perdamaian. Mereka melanjutkan babak baru dari konflik tetapi dengan sakit hati atau dendam yang lebih besar.

Kesehatian dalam bentuk komitmen membangun kehidupan bersama sangat dibutuhkan. Kesehatian bukan menghilangkan perbedaan, dan memaksakan semua pihak tunduk dalam cara pandang yang sama. Kesehatian lebih dimaksudkan sebagai pijakan atau titik tolak masing-masing pihak untuk memaknai perdamaian dengan caranya masing-masing.

\section{Saling Mengunjungi (ay 46b)}

Saling mengunjungi merupakan puncak perdamaian salah satu pemaknaan lain dari penyelesaian konflik. Yang dikembangkan dalam perilaku ini adalah memastikan bahwa perdamaian benar-benar telah terwujud. Saling mengunjungi merupakan bentuk keterbukaaan, penerimaan dan keamanan.
Jika saling mengunjungi dipahami dalam konteks kebudayaan di Indonesia, tuan rumah atau si penerima tamu akan merasa kehilangan harga diri apabila dia tidak dapat menjamin keamanan tamunya.

\section{Makna Teks Bagi Jemaat Masa Kini}

Konflik dalam jemaat menunjukkan bahwa fungsi kritis dan motivasi memperbaharui jemaat terus berlangsung. Namun tujuan tersebut harus dikomunikasikan dan diupayakan bersama sehingga tidak ada perasaan bahwa perkembangan atau penurunan kualitas hidup berjemaat terjadi karena tindakan dari oknum atau kelompok tertentu yang ingin merusak kesatuan dalam jemaat.

Belajar dari cara hidup jemaat mula-mula, maka point utama yang ingin ditekankan yakni setiap jemaat harus melandasi kebersamaannya dalam keyakinan dan keinginan membangun hubungan yang benar dengan Tuhan. Hanya dengan cara itu, arah kehidupan berjemaat ditempatkan dalam pola relasional yang digerakkan oleh kuasa Roh Kudus.

Mengenai aspirasi jemaat sebaiknya disampaikan dengan cara yang arif, bukan dengan memprovokasi anggota lainnya. Pada kondisi ini amat penting komunikasi intra dan interpersonal antara sang anggota jemaat dengan pengurus jemaat. Komunikasi yang dikembangkan harus berlandaskan semangat membangun persekutuan umat Tuhan. Hal ini penting supaya kedua belah pihak tidak menjadikan peristiwa duduk bersama sebagai ajang untuk adu pendapat atau untuk mempertahankan prinsip benar salah.

Pada konteks yang lain, apresiasi patut diberikan kepada jemaat-jemaat yang berani keluar dari kekakuan organisatoris dengan mengambil sebuah kebijakan di luar program kerja. Pengurus jemaat harus mampu melihat kebutuhan mendesak bagi jemaat, bukan membangun menara gading yang justru hanya menjaga keyamanan mereka dan mengabaikan solidaritas kepada mereka yang lemah dan menderita.

Perhatian yang besar perlu diberikan atas konflik yang terjadi karena pengaruh politik. Di era 
demokrasi yang sangat bebas di Indonesia, seringkali terjadi perpecahan dalam jemaat yang dipengaruhi oleh faktor eksternal berupa perbedaan politik. Di mana ada oknum-oknum tertentu yang berusaha menjadikan jemaat sebagai tempat untuk mendulang suara bagi tokoh politik yang mereka dukung. Kondisi tersebut tentu sangat rawan, karena jika jemaat terjebak dalam konflik politik, maka mereka kehilangan salah satu fungsinya yakni menjadi ruang yang memberi perlindungan terhadap keragaman pilihan.

Konflik yang disebabkan perbedaan pilihan politik nampaknya amat dipengaruhi oleh faktor individualisme yang tentu saja sarat dengan kepentingan. Mungkin saja oknum tertentu telah menerima janji-janji politik tertentu yang cukup menggiurkan sehingga mau menggunakan berbagai cara. Seharusnya dalam menyikapi perbedaan pilihan, yang bersangkutan harusnya menghargai pilihan orang lain. Lebih dari itu, setiap perbedaan pilihan harus kembali ditempatkan dalam prinsip-prinsip pengajaran Yesus, supaya mereka mampu melihat pemimpin yang la-

\section{DAFTAR RUJUKAN}

Barlett, David L. 2007. Pelayanan Dalam Perjanjian Baru. Terjemahan Liem Sien Kie dan Josafat Kristono. Jakarta: BPK Gunung Mulia.

Borg, M.J. 2000. Kali Pertama Jumpa Yesus Kembali: Yesus Sejarah dan Hakikat Iman Kristen Masa Kini. Terjemahan Ioanes Rakhmat. Jakarta: BPK Gunung Mulia.

Campbell, T. 1994. Tujuh Teori Sosial: Sketsa, Penilaian, Perbandingan, terjemahan F. Budi Hardiman. Yogyakarta: Kanisius.

Colpe, C. 1993. "The Oldest Jewish-Christian Community" dalam Jürgen Becker (ed)., Christian Beginnings; Word and Community From Jesus To Post-Apostolic Times. LouisvilleKentucky: Westminster/Jhon Knox Press.

Craig, C.T. 1943.The Beginning of Christianity. Nashvilee-New York: Abingdon Press.

Heyer, C.J. Den. 1997. Perjamuan Tuhan: Studi Mengenai Paskah dan Perjamuan Kudus Ber- yak dan benar-benar mendekati kriteria kepemimpinan dari segi iman Kristen.

\section{KESIMPULAN}

Manajemen konflik dari jemaat mula-mula menjadi rujukan yang kreatif bagi gereja masa kini dalam mengatasi konflik. Gereja dapat belajar cara jemaat mula-mula menghadapi konflik baik antar sesama anggota jemaat, maupun dengan pihak-pihak lain dalam masyarakat. Mereka tidak membiarkan konflik memecah kesatuan mereka sebaliknya menghadapi konflik dengan pikiran yang tenang dan berserah pada tuntunan Allah. Mereka duduk bersama membicarakan konflik sembari menumbuhkan kesehatian dalam perkumpulan ibadah maupun cara hidup yang menekankan solidaritas. Sedangkan terhadap konflik yang berhubungan dengan komunitas lain, mereka tidak membalasnya, sebaliknya melakukan kebaikan (walaupun terbatas dalam komunitas). Ini dimaksudkan supaya pihak yang lain tidak lagi menilai mereka sebagai ancaman.

tolak dari Penafsiran dan Teologi Alkitabiah. Jakarta: BPK Gunung Mulia.

Guthrie, D. 2012. Teologi Perjanjian Baru 3: Eklesiologi, Eskatologi, Etika. Terjemahan Lisda Tirtapradja Gamadhi. Jakarta: BPK Gunung Mulia.

Mandaru, H. F. 2007. "Kaya-Miskin dalam LukasKisah: Beberapa Lensa Pembacaan." Forum Biblika: Jurnal Ilmiah Populer, 21: 34-49.

Marshall, I.H. 2007. Acts. Surabaya: Momentum.

Mieu, W.C.J. 2014. "Merajut Manajemen Konflik" dalam Multikulturalisme: Kekayaan dan Tantangannya di Indonesia, ed. A. Eddy Kristiyanto dan William Chang. Jakarta: Komisi Teologi KWI-Penerbit Obor.

Napel, H.T. 2005. Kamus Teologi Inggris-Indonesia. Jakarta: BPK Gunung Mulia.

Nainggolan, Rahmat Hasudungan, 2018. "Pengaruh Cara Hidup Jemaat Mula-mula Berdasarkan 
Kisah Para Rasul 2:41-47 dan Relevansinya Pada Masa Kini.” Jurnal Pneustos, 1 (1): 90-108.

Prior, John Mansford. 2010. Menjebol Jeruji Prasangka: Membaca Alkitab Dengan Jiwa. Maumere: Ledalero.

Rusdiana, H.A, 2015. Manajemen Konflik. Bandung: Pustaka Setia

Sanderan, Rannu. 2015. "Skisma Dalam Gereja Protestan, Warisan Yang Dapat Ditolak" Jurnal Paria 2: 101-113.

Sarioa, Agustina B. 2014. Manajemen Konflik Dalam Gereja: Tinjauan Terhadap Suatu Resolusi Konflik Dari Perspektif Teori Mediasi, Tesis Magister Manajemen UKSW, 2014: 54-60

http://repository.uksw.edu/handle/12345678 9/6113

Sihombing, L. 2015. "Isu Etika Sosial Dalam Gereja Yang Mula-mula" Jurnal Amanat Agung, 11 (1):169-179.

Singgih, E.G. 2009. Dua Konteks: Tafsir-tafisr Perjanjian Lama sebagai Respons atas Perjalanan Reformasi di Indonesia. Jakarta: BPK Gunung Mulia.
Singgih, E.G. 2016. "Masa Depan Membaca dan Menafsir Alkitab di Indonesia" dalam Teologi Yang Membebaskan dan Membebaskan Teologi, Wahyu S. Wibowo dan Robert Setio, ed. Yogyakarta: Yayasan TPK IndonesiaFakultas Teologi UKDW.

Sutoyo, Daniel, 2014. "Gaya Hidup Gereja Mulamula Yang Disukai Dalam Kisah Para Rasul 2:42-47 Bagi Gereja Masa Kini.” Jurnal Antusias, 3 (6): 1-31.

Tanhidy, Jamin. 2014. "Makna Makan Dalam Perspektif Alkitab: Suatu Refleksi Bagi Pelaku Wisata Kuliner" Jurnal Simpson: Jurnal Teologi dan Pendidikan Agama Kristen, 1 (1):121-130.

Thiessen, G. 2005. Gerakan Yesus; Sebuah Pemahaman Sosiologis Tentang Jemaat Kristen Perdana. Maumere: Ledalero.

Yang, L.K. 2007. "Gereja Mula-mula: Renungan Atas Kisah Para Rasul 2:41-47” dalam Menghayati Kalam Dalam Hening: Kumpulan Karangan terpilih Liem Khiem Yang, editor. Martin L. Sinaga. Jakarta: LAI. 